\title{
Insulin and insulin-like growth factors act as renal cell cancer intratumoral regulators
}

\author{
Wojciech Solarek $^{1,2} \cdot$ Michal Koper $^{3} \cdot$ Slawomir Lewicki $^{4} \cdot$ Cezary Szczylik $^{1,25,6} \cdot$ Anna M. Czarnecka ${ }^{1}$ (D)
}

Received: 3 December 2018 / Accepted: 25 February 2019/Published online: 30 March 2019

(C) The Author(s) 2019

\begin{abstract}
The risk of renal cell carcinoma development is correlated with obesity and type II diabetes. Since insulin and insulin-like growth factors play a key role during development of both metabolic diseases, these molecules may be important in RCC pathophysiology We investigated the effect of insulin and IGFs on RCC cells using in vitro model with 786-O, 769-P, Caki-1, Caki-2, ACHN cancer cell lines. Cancer cells were compared with normal kidney cells - PCS-400-010 and HEK293. The growth, viability of cells as well as migration rate were assessed upon hormonal stimulation. The insulin receptor and Insulin-like growth factor 1 receptor presence were evaluated and the expression of 84 genes related to insulin signaling pathway. In all RCC cell lines IGF-1R expression was confirmed in contrast to IR, which was expressed only in control HEK293 cell line. Insulin and IGFs stimulated RCC cells growth and migration rate. Insulin, IGF-1 and IGF-2 triggered both IR and IGF-1R phosphorylation. Analyzed RCC did not secret insulin, IGF-1 or IGF-2 and were not activated in autocrine-paracrine signaling loop. Insulin and IGFs stimulations triggered downregulation of PI3K-Akt-mTOR and Ras-MAPK pathway gens, as well as DOK2-3, INS, FRS3, IRS1-2, IGF1R - genes encoding insulin receptor-associated proteins. In conclusion, we showed that IGFs and insulin may play a stimulatory role for renal cancer cells, thus they can possibly affect renal cancer tumorigenesis and progression on cellular level.
\end{abstract}

Keywords Renal cell carcinoma $\cdot$ Insulin $\cdot$ Insulin-like growth factor $\cdot$ Insulin-like growth factor receptor $\cdot$ Insulin receptor

Electronic supplementary material The online version of this article (https://doi.org/10.1007/s12079-019-00512-y) contains supplementary material, which is available to authorized users.

Anna M. Czarnecka

anna.czarnecka@gmail.com

1 Department of Oncology with Laboratory of Molecular Oncology, Military Institute of Medicine, Szaserow 128, Warsaw 04-141, Poland

2 School of Molecular Medicine, Medical University of Warsaw, Warsaw, Poland

3 Institute of Genetics and Biotechnology, Faculty of Biology, University of Warsaw, Warsaw, Poland

4 Department of Regenerative Medicine and Cell Biology, Military Institute of Hygiene and Epidemiology, Warsaw, Poland

5 Present address: Department of Oncology, European Health Centre, Otwock, Poland

6 Present address: Medical Center for Postgraduate Education, Warsaw, Poland

\section{Introduction}

Kidney cancer with about 403,262 new cases diagnosed and 175,098 deaths worldwide is the 16 th most common cancer (Bray et al. 2018). With renal pelvis cancer, RCC was predicted to be diagnosed in 63,340 new cases and to cause 14,970 deaths in United States in 2018 (Siegel et al. 2016). It is well known, that diagnosis of obesity and/or type II diabetes mellitus is correlated with the increased risk of RCC development (Murai and Oya 2004; Larsson and Wolk 2011). These diseases are related to deregulation of insulin (IN) and insulinlike growth factors (IGFs) signaling, which are also expected to influence RCC tumorigenesis and progression (Solarek et al. 2015; Labochka et al. 2016; Tracz et al. 2016).

Insulin is produced in the pancreatic islet $\beta$ cells as a prepro-hormone from INS gene located in $11 \mathrm{p} 15.5$, then gradually cleaved to form active peptide. IN regulates carbohydrate and fat metabolism on cellular and organismal level. Insulin activity is exerted via the Insulin Receptor (IR). IR is mainly expressed in adipose tissue, muscle and liver cells (Matyszewski et al. 2015a, b, c). Interestingly, high serum insulin concentration inhibits autophagocytosis, proteasome 
activity and apoptosis, which may lead to the antiapoptotic and mitogenic effects (Reuveni et al. 2013; Matyszewski et al. 2015a, b, c). On the other hand IR expression on $\mathrm{RCC}$ tumor cells is inversely associated with tumor stage or presence of distant metastases. At the same time hyperinsulinemia was also reported not to enhance tumor growth in murine RENCA RCC animal model (Solarek et al. 2015; Takahashi et al. 2017).

IGFs are produced mainly in liver under the control of growth hormone and in turn regulate cells growth and proliferation. Ligand binding with IGF1R (or IR) leads to activation of tyrosine kinase signaling and phosphorylation of insulin receptor substrate proteins (IRS). Activated IRS in turn induce two crucial intracellular signaling pathways: PI3K-Akt-mTOR pathway and Ras-MAPK pathways that regulate cell proliferation, apoptosis and potentially cancer development (Pollak 2008). In most RCC cases of VHL protein inactivation is found and it was proven that in turn this leads to uncontrolled stimulation of IGF1R-mediated signaling pathway promoting RCC invasiveness through the interaction with RACK1 and subsequent Akt and MMP-2 activation (Datta et al. 2000). It is highly probable that deregulated IR and IGF1R signaling promote development of several cancers but the activity and function of this pathway has not been coherently studied in RCC. The role if insulin and IGFs in RCC pathophysiology has been elusive until now. It may be hypothesized that hyperinsulinemia enhance cancer cells growth and proliferation through insulin's effect on its cognate receptor, and also by the IGFs pathway activation (Frasca et al. 2008; Solarek et al. 2015).

The aim of the study was to verify the hypothesis that insulin and insulin-like growth factors stimulate renal cancer cells proliferation and viability excessively in comparison to normal kidney cells. We aimed to verify the presence of insulin and insulin-like growth-factor autocrine-paracrine signaling loop in RCC cells and to describe subsequent activation of insulin-related signaling pathway. The ultimate goal of the study was to assess the role of insulin and insulin-like growth factors in the proliferation, growth and migration of primary and metastatic tumor derived renal cancer cells.

\section{Materials and methods}

\section{Routine cell culture}

The renal cancer cell lines 786-O (CRL-TM), 769-P (CRL1933 ${ }^{\mathrm{TM}}$ ), Caki-1 (HTB46 $\left.{ }^{\mathrm{TM}}\right)$, Caki-2 (HTB-47 ${ }^{\mathrm{TM}}$ ), ACHN (CRL1611 $\left.{ }^{\mathrm{TM}}\right)$ and control cell lines PCS-400-010 and HEK293 (CRL 1573 ${ }^{\mathrm{TM}}$ ) were obtained from American Type Culture Collection (ATCC) Bioresource Center (Manassas, VA, USA). The characteristics of each cell line are presented in Table 1. The 786-O, 769-P, Caki-1, Caki-2, ACHN cell lines were routinely cultured in RPMI-1640 with GlutaMAX ${ }^{\mathrm{TM}}$ Supplement medium (Life Technologies, CA, USA) supplemented with $10 \%$ fetal bovine serum (FBS; Biochrom $\mathrm{GmbH}$, Cambridge, UK) and $1 \%$ antibiotic solution (penicillin- streptomycin; Invitrogen, CA, USA), in a $37^{\circ} \mathrm{C}$ humidified atmosphere with 5\% CO2.

All cell lines were screened for Mycoplasma contamination on a regular basis with Mycoplasma Detection Kit (Jena Bioscience, PP-401 L) and only negative passages were used for the presented experiments. All cell lines passages were not higher than 15. Cell lines were authenticated with ATCC service with short-tandem repeat profiling (STR Profiling Cell Authentication Service, LGC Standards, Lomianki, Poland).

\section{Experimental cell culture (hormonal stimulation cell culture)}

Renal cancer cells or control cells were cultured under standard conditions in cell incubator $\left(37^{\circ} \mathrm{C}, 5 \% \mathrm{CO}_{2}\right)$. Cells were moved to 6/24/96 wells plates or T25 flasks. In order to observe influence of insulin and IGFs on cancer cells we used serum free conditions. After $24 \mathrm{~h}$ cells were rinse with PBS twice and RPMI 1640 medium with 0,1\% BSA (SigmaAldrich, USA) was used (serum starved conditions). After next $24 \mathrm{~h}$ RPMI 1640 medium with 0,1\% BSA and investigated growth factors and/or inhibitors: Insulin (Human Recombinant Zinc, Gibco by Invitrogen, CA, USA), IGF1 (Recombinant Human Insulin Like Growth Factor-1), IGF2 (Recombinant Human Insulin Like Growth Factor-2) (each $100 \mathrm{ng} / \mathrm{ml})$, IR inhibitor - HNMPA-(AM) $(100 \mu \mathrm{M})$, IGF1R

Table 1 Investigated cell lines

\begin{tabular}{|c|c|c|}
\hline Cell line & Origin & Histopathology \\
\hline 786-O (CRL-1932 & Primary tumor & Primary Clear Cell Carcinoma (RCC) \\
\hline 769-P (CRL-1933 & Primary tumor & Primary Clear Cell Carcinoma (RCC) \\
\hline Caki-1 (HTB46'TM) & Metastatic tumor & Kidney Carcinoma Metastasis to Skin \\
\hline Caki-2 (HTB-47TM) & Primary tumor & Primary Clear Cell Carcinoma (RCC) \\
\hline ACHN (CRL1611 & Metastatic tumor & From the Malignant Pleural Effusion (RCC) \\
\hline HEK293 (CRL 1573M) & Embryonic kidney & Human Embryonic Kidney Cells \\
\hline PCS-400-010 & Healthy kidney & Primary Renal Proximal Tubule Epithelial Cells \\
\hline
\end{tabular}


Inhibitor - PPP (50 nM) (Merck Millipore, Darmstadt, Germany) was used for culture.

\section{Measurement of cell viability}

Cells were seeded in 96 well plates $\left(10^{4}\right.$ cells $\left./ \mathrm{ml}\right)$ and cultured under standard conditions $\left(37{ }^{\circ} \mathrm{C}, 5 \% \mathrm{CO}_{2}\right)$ according to the experimental protocol. Viability was measured in $72 \mathrm{~h}$ and $96 \mathrm{~h}$ with AlamarBlue(resazurin) (Thermo Fisher Scientific, MA, USA) assay according to manufacturer's protocol. Absorbance was read by microplate reader Multiskan GO and analyzed using ScanIt ${ }^{\mathrm{TM}}$ software package (Thermo Fisher Scientific, MA, USA). Growth curves were acquired with cells seeded $\left(10^{4}\right.$ cells $\left./ \mathrm{ml}\right)$ in T25 flasks and cultured under standard conditions according to the experimental protocol. Each day of experiment from one of T25, cells were harvested by trypsynization ( $0.25 \%$ trypsin, $0.03 \%$ EDTA solution, Life Technologies, Carlsbad, CA, USA) and counted in an automated cell counter (MOXI Z, Orflo Technologies, Ketchum, ID, USA). All experiments have been conducted in at least 3 replicates.

\section{Wound-healing assay}

Cells were seeded in 24-well plates and cultured according to the routine protocol. Cell migration was assessed by the wound-healing assay (Grada et al. 2017). Cells were rinse with PBS twice and RPMI with $0,1 \%$ BSA medium was added (serum starved conditions). After $24 \mathrm{~h}$ RPMI with $0,1 \%$ BSA medium with investigated factors and inhibitors: Insulin, IGF1, IGF2 (each $100 \mathrm{ng} / \mathrm{ml}$ ) was added and a wound was introduced in a cell monolayer using a pipette tip (at least 95\% of confluence). The 'wounded' areas were photographed at $0,24,48,72,96 \mathrm{~h}$. The relative migration distances were analyzed using Image J Software (version 1.41; National Institutes of Health). All experiments have been conducted in at least 2 replicates.

\section{FACS}

Cells were seeded in 6 well plates and cultured under standard conditions $\left(37^{\circ} \mathrm{C}, 5 \% \mathrm{CO}_{2}\right)$ according to the routine protocol. Cells were washed twice in PBS and detached by Trypsin/ EDTA for 5 min at $37^{\circ} \mathrm{C}$. The cells were subsequently washed once in PBS and incubated with $5 \mu 1$ sample of PE conjugated $\mathrm{mAb}$ anti-IGF1R (CD221), anti-IR (CD220) or mouse IgG K isotype control (Becton Dickinson, NJ, USA) for $30 \mathrm{~min}$ at $4{ }^{\circ} \mathrm{C}$ in PBS. The cells were washed twice in PBS to remove unbound antibody, resuspended in PBS-buffered formalin and then analyzed using a FACS flow cytometer (FACSCalibur ${ }^{\mathrm{TM}}$, Becton Dickinson, NJ, USA) according to standard settings at $488 \mathrm{~nm}$. Each sample was prepared in duplicate and analyzed for IR and IGF1R expression.

\section{Multiplex analysis}

Cells were seeded in 6 well plates and cultured under standard conditions $\left(37{ }^{\circ} \mathrm{C}, 5 \% \mathrm{CO}^{2}\right)$ according to the experimental protocol (serum starved cells). $10 \mathrm{~min}$ after the addition of insulin, IGF-1, or IGF-2 cells were washed twice with icecold PBS, lysed with ice-cold Lysis Buffer containing Halt Protease and Phosphatase Inhibitor (Thermo Fisher Scientific, MA, USA). Total protein concentration was measured with the BCA Protein Assay (Thermo Fisher Scientific, MA, USA). Total and phosphorylated IGF1R and IR were detected with MILLIPLEX MAP Total/Phospho Mitogenesis RTK Magnetic Bead 7-Plex Kit (Merck Millipore, Darmstadt, Germany). Alternatively after $24 \mathrm{~h}$ cells supernatant was collected and Insulin, IGF1 and IGF2 concentrations were measured using Human Insulin ELISA for insulin and MILLIPLEX MAP Human IGF-I, II Magnetic Bead Panel (Merck Millipore, Darmstadt, Germany). The results were shown as a MFI - mean fluorescent intensity of three repeats for each sample.

\section{Elisa}

Cells were seeded in 6 well plates and cultured under standard conditions $\left(37^{\circ} \mathrm{C}, 5 \% \mathrm{CO}^{2}\right)$ according to the routine cell culture protocol. For IR expression measurement cells were washed twice with cold PBS, lysed with ice-cold lysis RIPA buffer (Sigma-Aldrich, MO, USA) containing Halt Protease and Phosphatase Inhibitor (Thermo Fisher Scientific, MA, USA). Total protein concentration was measured with the BCA Protein Assay (Thermo Fisher Scientific, MA, USA). IR concentration was measured with STAR IR ( $\beta$ subunit) ELISA Kit (Merck Millipore, Darmstadt, Germany).

\section{RT-PCR}

Cells were seeded in T25 flasks and cultured under standard conditions $\left(37^{\circ} \mathrm{C}, 5 \% \mathrm{CO}^{2}\right)$ according to the experimental protocol. After $24 \mathrm{~h}$ total RNA samples from three independent biological replicates were isolated using miRNeasy Mini Kit (Qiagen, CA, USA), according to the manufacturer's instructions. RNA quality and concentration were measured using RNA Nano chip on the 2100 Bioanalyzer instrument (Agilent Technologies) and only RNA samples with RIN value (RNA Integrity Numbers) not lower than 9.0 were selected for reverse transcription. cDNA was synthesized from $400 \mathrm{ng}$ of RNA using the RT2 First Strand Kit (Qiagen, CA, USA), according to the manufacturer's instructions. RT-qPCR was performed in triplicate, using one plate for one experiment repetition (384-well plates divided in to 96-well parts for control and each investigated condition). To each well of 384-well plates (RT ${ }^{2}$ ProfilerTM PCR Array Human Insulin Signaling Pathway) we added $10-\mu \mathrm{l}$ reaction mixture containing $5 \mu \mathrm{l}$ of 
2x $\mathrm{RT}^{2}$ SYBER Green Mastermix (Qiagen, CA, USA) and $5 \mu l$ of cDNA synthesis reaction with RNase-free water. Reactions were pipetted using JANUS ${ }^{\circledR}$ Extended Integrator 8 -tip Automated Workstation (PerkinElmer). C $p$ values were calculated using LightCycler ${ }^{\circledR} 480$ Software 1.5 (Roche Diagnostics), based on the Second Derivative Maximum Method. CT values were exported to an Excel file to create a table of CT values. This table was then uploaded on to the data analysis web portal at http://www.qiagen.com/geneglobe. Samples were assigned to controls and test groups. CT values were normalized based on a/an Automatic selection from full panel of reference genes. The data analysis web portal calculates fold change/regulation using delta delta CT method, in which delta $\mathrm{CT}$ is calculated between gene of interest (GOI) and an average of reference genes (HKG), followed by delta-delta CT calculations (delta CT (Test Group)-delta CT (Control Group)). Fold Change is then calculated using $2^{\wedge}$ (-delta delta CT) formula.

\section{Statistical analyses}

The data were analyzed as the means with standard deviation (SD) of at least three experiments. Data fitting and statistical analysis were performed and graphs were prepared using Microsoft's Excel program 2013 (Washington, USA) and Biovinci web version (https://vinci.bioturing.com). Statistical analysis was performed using ANOVA followed by Tukey's HSD test as statistical methods that allow estimation of interindividual variability in intra-individual patterns of change over time. Differences and relationship were considered statistically significant when $P=0.05$. Gene expression level (RT-qPCR) was also evaluated with t-test .

\section{Results}

\section{RCC cells express IGF1R, but not IR}

Among all investigated RCC cell lines, including primary tumor derived and metastasis derived cell lines as well as normal cell lines, IGF1R expression was confirmed with FACS (Fig. 1e, Suppl. 1). ACHN, Caki-2 and HEK293 cell lines presented the highest number of expression-positive cells, which was more than $90 \%$. The presence of IGF1R was also confirmed with multiplex Luminex analysis using cells lysates (Fig. 1b, d). In this analysis the highest expression was detected in ACHN, HEK293 and 786-O cell lines. IR surface expression was found only in HEK293 embryonic kidney cell line. Only $11 \%$ of HEK293 cells expressed this receptor (Fig. 1e-FACS). The result was confirmed in cell lysate using two another methods - ELISA assay (data not shown) and multiplex Luminex analysis (Fig. 1a, c). In ELISA assay the concentration of $\beta$ subunit of insulin receptor was only $2,77 \mathrm{ng} / \mathrm{ml}$ in this kidney cell line. In all RCC cell lines and adult renal proximal tubule epithelial cells no expression of IR $\beta$ subunit protein was found. This result was confirmed with in multiplex magnetic analysis. The mean fluorescence intensity (MFI) for IR in HEK293 cell line was 6036.19 a.u. and neglectable (below 300 a.u.) for all other investigated cell lines. Using all three methods we show the lack of IR receptor expression on RCC cell lines, and/or IR accumulation within RCC cells, despite the fact that those cell lines are responsive to insulin stimulation (as described below).

\section{Insulin and IGFs stimulate RCC cells proliferation and migration}

Both primary tumor derived, and metastatic tumor derived RCC cells, as well as embryonic kidney cells (HEK-293), were found to be fast proliferators in contrast to adult renal proximal tubule epithelial cells (PCS-400-010). PCS-400-010 present slow proliferation rate, also in hormone-supplemented medium with Insulin $5 \mu \mathrm{g} / \mathrm{ml}$ (and Triiodothyronine $10 \mathrm{nM}$, rh EGF $10 \mathrm{ng} / \mathrm{mL}$, Hydrocortisone $100 \mathrm{ng} / \mathrm{mL}$, Epinephrine $1.0 \mu \mathrm{M})$. For all renal cells serum free conditions limit the exponential growth phase. Most of cell lines are able to survive serum restriction for 3 to 4 days and become necrotic at day 5 th upon serum starvation.

Both metastatic cell lines (Caki-1, ACHN) and control normal renal embryonic and adult renal cell lines (HEK293 and PCS-400-010) were significantly proliferation-responsive to stimulation with insulin (Fig. 2.), with most profound effect on embryonic cells (HEK293) and metastatic RCC cells (Caki-1). Addition of insulin to primary tumor derived RCC cell lines (Caki-2, 769-P, 786-O) did not affect it viability or proliferation in first $72 \mathrm{~h}$ after stimulation. Insulin receptor inhibition with Hydroxy-2-naphthalenylmethylphosphonic Acid Trisacetoxymethyl Ester (HNMPA-(AM)) - Insulin receptor tyrosine kinase inhibitor - did not result with specific insulin-only stimulation inhibition (Fig. 3., Suppl. 2). Inhibition of IR tyrosine kinase signaling as well as serine and tyrosine autophosphorylation decreases the viability of RCC cells in all tested conditions, including insulin (and IGFs) stimulation. In fact the decreased viability of RCC cells in growth factor restriction conditions with concurrent HNMPA-(AM) treatment is expected to result from decreased insulin-stimulated glucose oxidation. Finally analyzed RCC were found not to secret insulin, IGF1 or IGF2 in autocrine manner. In all tested supernatants no Insulin, IGF1 nor IGF2 was detected in (serum-free) culture (Tables 2, 3 and 4).

On the contrary to delayed proliferation effect, significant insulin influence on migration and proliferation rate of primary tumor derived RCC cells' was observed in wound healing assay over 3 days (Fig. 2.). Concordantly to the primary tumor derived RCC cells' insulin rapidly 

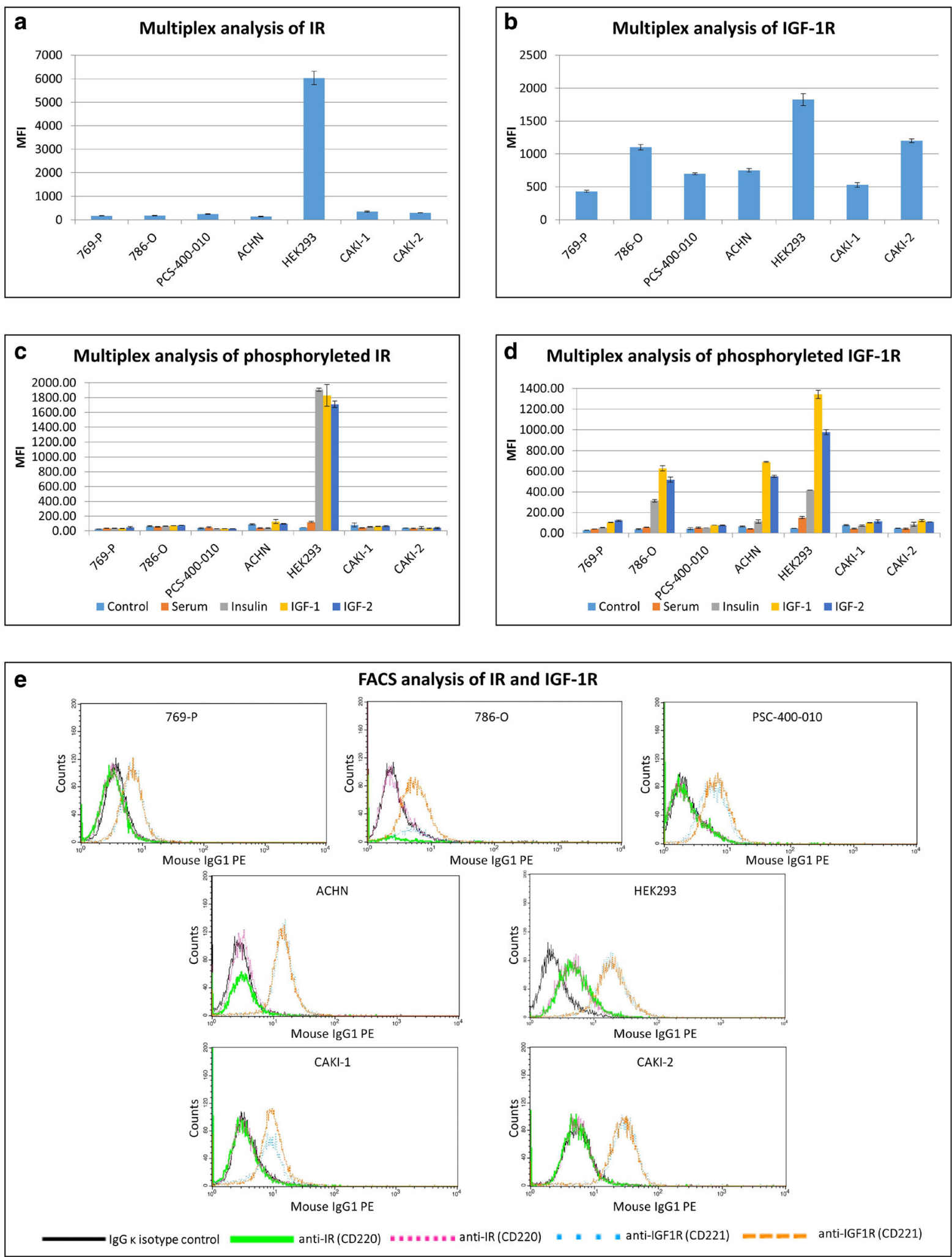

Fig. 1 Total and phosphorylated IR and IGF1R analysis. The only HEK293 cell line express IR receptor. It is present in cell lysate what was assessed with multiplex Luminex analysis (relative quantity shown as MFI - mean fluorescent intensity of three repeats for each sample) (a). The expression of IR was also observed on the cell surface in FACS analysis with PE conjugated mAb anti-IR (CD220). Green and pink curves represents two repeats of IR analysis, blue and orange represents
IGF-1R analysis and black stays for isotype control (e). These results were also confirmed with ELISA assay. Treatment with each investigated molecule (insulin, IGF1, IGF2) lead to IR phosphorylation (c). Both cancer cell line and control cell line expressed IGF1R visible on cell surface (e) and in cell lysate (b). IGF1R phosphorylation was observed after insulin, IGF1 and IGF2, what was most strongly pronounced in cell lines 786-O, ACHN and HEK293 (d) 

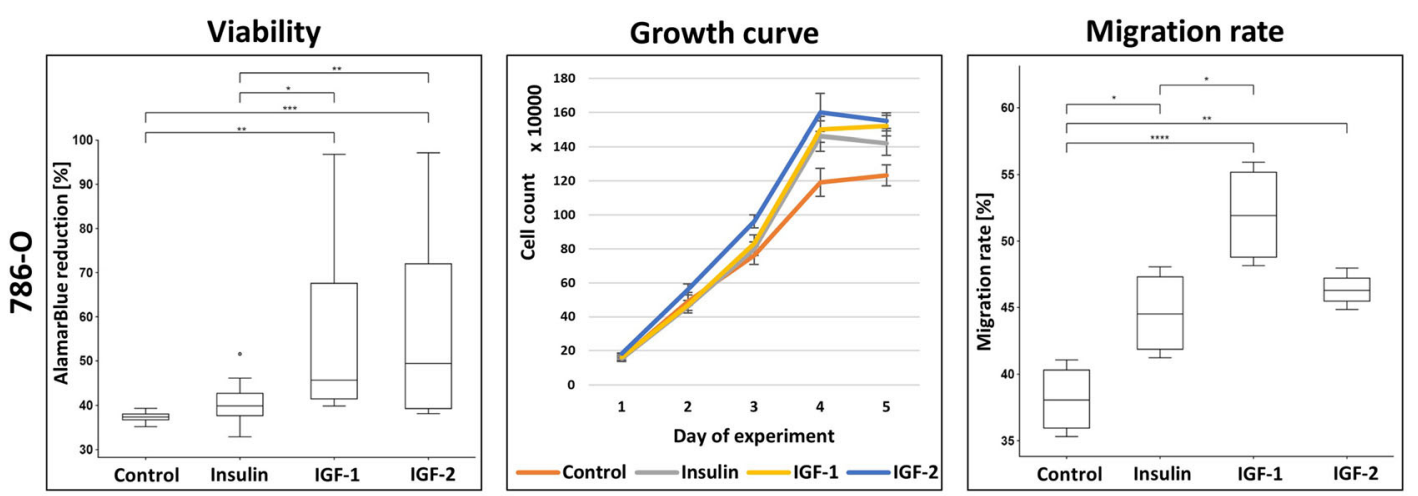

Wound Healing
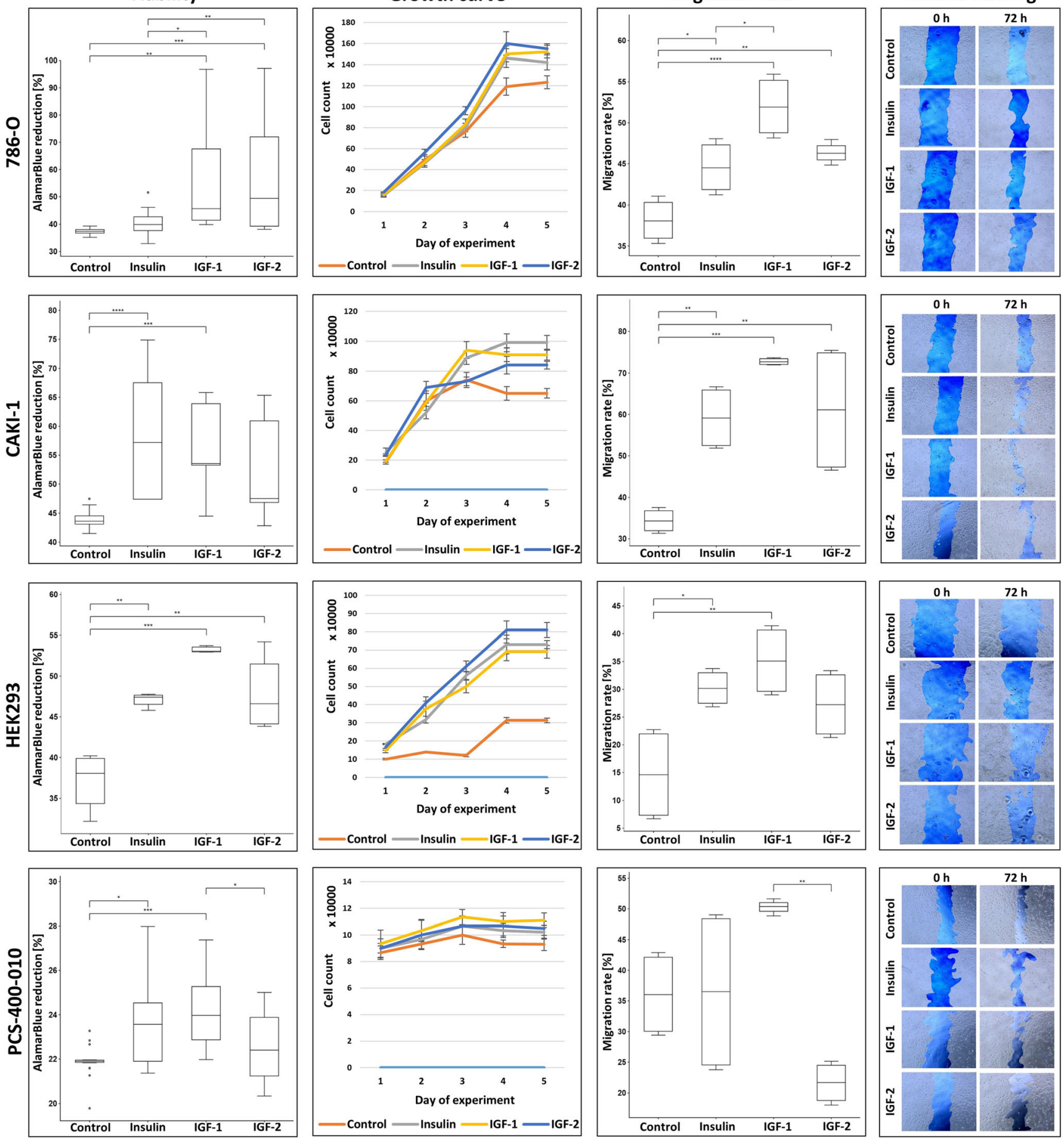

Fig. 2 Cells viability and migration rate after insulin, IGF1 or IGF2 stimulation. First column present cells viability measured in AlamarBlue test. Median (line) and interquartile range (box) are shown along with minimum and maximum data values. In this assay resazurin upon entering living cells is reduced to resorufin, which can be quantify by absorbance reading (Y-axis). Presented results were acquired $72 \mathrm{~h}$ after addition of insulin, IGF1 or IGF2. The second column show cells growth curves, starting from 1st day of experiment ( $24 \mathrm{~h}$ after addition of investigated compounds) till day 6 th when cells reached plateau phase of growth. Third column visualize migration rate of investigated cell lines

after addition of insulin, IGF1 or IGF2 in $72 \mathrm{~h}$ (786-O, CAKI-1, HEK293) or $96 \mathrm{~h}$ (PCS-400-010 due to slow proliferation rate) in wound healing assay. The migration rate [\%] was calculated as a percentage decrease in wound area between start and 48 or $96 \mathrm{~h}$ of experiment, calculated with Image J software (Y-axis). Fourth column represent wound healing assay visualization with enhanced contrast (Image J) in wound area in the beginning and 72 or $96 \mathrm{~h}$ of experiment. Statistical analysis was performed using ANOVA followed by Tukey's HSD (Biovinci web version - https://vinci.bioturing.com). * $P \leq 0.05$, ** $P \leq$ $0.01, * * * P \leq 0.001, * * * * P \leq 0.0001$ 
increased migration rate of all metastatic cancer cell lines and embryonic kidney cell line. The increased potential of wound healing was significant in metastatic cell lines ( $p<0.005$ vs $p<0.05$ for primary cancer site cell lines), which suggest that insulin conduct its stimulating signal through the IGF1R receptor in this case.

All cell lines except Caki-2 were strongly responsive to stimulation with IGF1. Both the viability and migration rate where significantly increased after IGF1 stimulation. This effect was most prominent on day 3rd and 4th of stimulation. In Caki-2 cells response to IGF1 stimulation was insignificant. The increased viability was more profound in metastatic RCC cell lines than in primary cancer derived RCC cell lines $(\mathrm{p}<$ 0.005 vs $p<0.05$ respectively). Exposure to IGF2 stimulated viability and migration rate of all cell lines except primary normal kidney cell line, which was not responsive to this stimulation. Viability (cellular metabolism) of Caki-1 cell line after IGF2 stimulation was not significantly increased (AlamarBlue) but proliferation (growth curve) and migration (wound healing assay) were augmented (Fig. 2.). Renal cells stimulation by IGF1 or IGF2 was inhibited with HNMPA-(AM) nor PPP. Both IGF inhibitors decreased cell viability irrespectively of stimulating growth factor.

\section{Both IR and IGF1R are phosphorylated after IGF1, IGF2 and insulin stimulation}

The phosphorylation of IR(panTyr) and IGF1R (panTyr) was assessed in cell lysate with phosphatases and phosphorylases inhibitors (Fig. 1. C, D - Luminex assay). The most significant phosphorylation of IGF1R after IGF1 stimulation was observed in 786-O, ACHN and HEK293 cells. IGF2 stimulation was less effective, but also most profound in 786-O, ACHN and HEK293 cells. Interestingly, the stimulation with IN resulted in phosphorylation of IGF1R in 786-O, Caki-2 and HEK293 cell lines. The insulin receptor that is expressed only in HEK293 cells, was phosphorylated upon its ligand (IN) binding. Also IGF1 and IGF2 induced IR phosphorylation in these cells (Fig. 1c, d).

\section{Insulin and IGFs signaling pathway is affected after insulin, IGF1 and IGF2 stimulation}

The insulin stimulation lead to significant down-regulation of genes related to MAP Kinase Signaling - such as FOS and $M A P 2 K 1$ - expression in 786-O cells or RRAS2 gene in HEK293 cell line (Table 5, Fig. 4). No statistically significant influence on preselected gene expression was found in Caki-1 cell line after insulin stimulation. In HEK293 cell line we also observed decreased expression of insulin receptor-associated proteins genes including $F R S 3$, IGF1R or IGF2. Insulin stimulation resulted in minor increase in $P R L$ gene expression in Caki-1 and HEK293 cell lines.
After IGF1 stimulation we notice decrease in expression of transcription regulator AEBP1 and PI3 Kinase Signaling protein AKT genes in Caki-1 metastatic RCC cell line. The IGF1 induction of HEK293 cell line resulted in increased expression of Downstream of Tyrosine Kinases (DOK3) gene, which encode protein associated with insulin receptor. In this cell line we also observed decreased expression of $F B P 1$, which is engaged in glucose metabolism and $J U N$ transcription factor. We do not detect the significant change in gene expression after IGF1 stimulation in 786-O cell line.

Subsequently to IGF2 stimulation modulated expression of multiple genes in all investigated cell lines. In 786-O primary tumor cell line we observed decrease expression of genes of insulin-associated proteins (IRS2, $C B L$ ), transcription regulators (AEBP1), PI3 kinase signaling (AKT1, BCL2L1) as well as lipid metabolism genes $(A C O X 1)$. In metastatic Caki-1 cell line we showed the down-regulation of transcription factor gene AEBP1 and PI3 kinase signaling component (AKT3). IGF2 conditioning of HEK293 cell line leads to increased expression of HRAS gene of MAP kinase pathway and decreased expression of insulin-associated proteins (FRS3, $I G F 1 R$ ) genes, as well as transcription regulator $J U N$ gene and carbohydrate metabolism $F B P 1$ gene.

In general IN and IGF stimulation did not substantially deregulate gene expression in RCC cells, but actually downregulation of expression was detected in most cases. The lowest relative expression was detected in insulin receptorassociated pathway DOK1-3, INS, FRS3, IRS1-2, IGF1R. Interestingly in the cancerous cell lines missing IR receptor but not in HEK293 cells - insulin, IGF1 or IGF2 stimulation induced substantial down-regulation of the INS gene expression. Another difference between RCC and normal kidney cell lines was observed in Downstream of Tyrosine Kinases $(D O K)$ genes expression. Every stimulation of cancer cell lines missing IR lead to down-regulation of $D O K$ genes, whereas in control cell line with IR insulin or IGF1 stimulation resulted in up-regulation of $D O K$ genes expression. What is also interesting we observed increased expression of $P R L$ gene after stimulation with insulin or IGF1 in Caki-1 and HEK293 cell lines.

\section{Discussion}

IGFs and insulin system is complex and dependent on three ligands (insulin, IGF1 and IGF2) and at least three receptors IR, IGF1R as well as IGF type 2 receptor (IGF2R), known as a mannose 6-phosphate receptor (M6P-R), which binds IGFs but does not transduce signal (Leboulleux et al. 2001; Zhang et al. 2010). IR and IGF-IR most often are covalently bound receptor dimers and localize on cell membrane. Although IR and IGF-IR function most often as homodimer, nevertheless hybrid receptors of IR and IGF-IR have also been described 

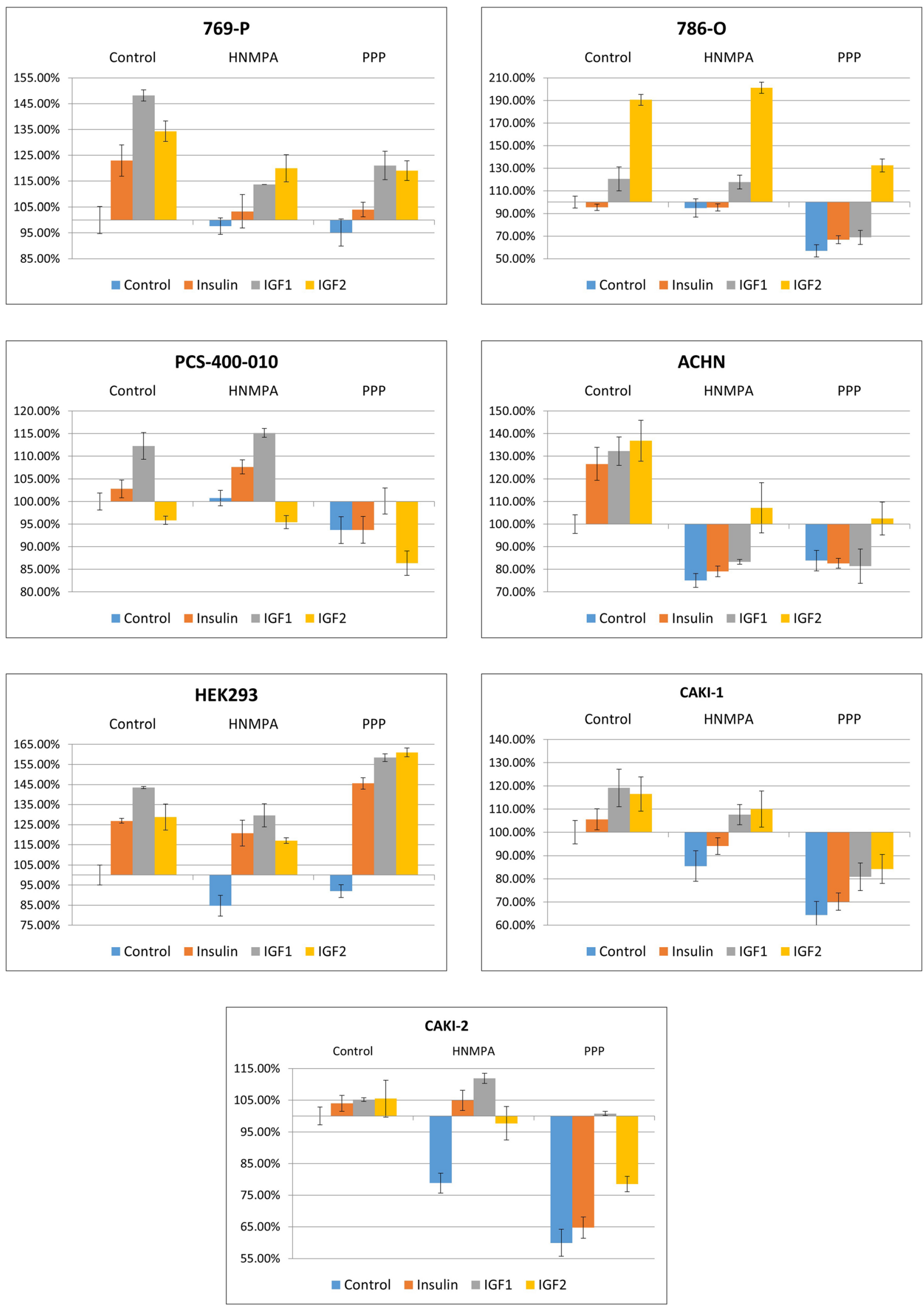
Fig. 3 The influence of IR and IGF1R inhibitors on cells viability. The cells viability was assessed using Alamar blue test in 72th hour of experiment (all investigated factors and inhibitors were added at beginning of experiment). Insulin receptor inhibition with HNMPA(AM) (not specific inhibition) decreased the viability in all tested conditions. PPP (IGF1R inhibitor) dismiss the effect of insulin. After IGF1 or IGF2 there was no specific differences in the viability of cells cultured with HNMPA-(AM) nor PPP

before. Those hybrid receptors, irrespective of their splice variants have affinity for insulin, IGF-I, and IGF-II binding, but for IGF-I it is at least 50-fold higher affinity than for insulin and binding characteristics of insulin and IGF-I to both hybrid receptors is similar to regular IGF-IR homodimer (Slaaby et al. 2006). Differences in the activation of different intracellular signaling pathways leading to distinct regulations of gene expression by homo- and heterodimers. Studies proved that intracellular domain of the IR is more effective in phosphorylating IRS-1 thus inducting the expression of genes involved in metabolic pathways; whereas, intracellular domain of IGF1R phosphorylate more potently Shc and Gab-1, which leads to the activation of genes involved in proliferation (Cai et al. 2017). As we have shown here IR is not widely distributed on RCC cells surface, but this does not exclude IN stimulation via alternative receptors. We believe that IGFRs and hybrid receptors are responsible for insulin effects on these RCC cells, as it was recently shown for breast cancer cells (Chen et al. 2018).

In healthy individuals IR is expressed in nearly all absorptive epithelial cells along the renal tubule, including proximal tubule epithelial cells, which give origin to RCC (Tiwari et al. 2013). Strong expression of IR is typical in proximal and distal tubules of normal human renal cortex in healthy individuals, while a significant reduction is found in type 2 diabetic patients, insulin-resistant cases and in those with diabetic nephropathy (Gatica et al. 2013). Insulin impact both metabolic and transport functions of the proximal tubule cells, including gluconeogenesis. IRs are localized on the basolateral side of proximal tubule cells bind serum insulin and activate intracellular signaling (Sasaki et al. 2017). IR expression in RCC tumors was recently shown to be inversely associated with disease progression. IR expression in RCC tumors is low in patients with tumor stage pT2 to pT4 and in those with metastatic disease (Takahashi et al. 2017). We have confirmed IR and IGF1R RCC cell surface expression using FACS with PE conjugated $\mathrm{mAb}$ antiIGF1R (CD221) or anti-IR (CD220). Our results confirm down-regulation of IR expression in RCC cancer cells, but confirm the utility of cell culture models for hormonal investigations in the field of RCC. We have previously shown and confirm with this study that analyzed RCC cell lines represent feasible model for endocrine research in urologic oncology including clear cell and papillary RCC, 2D and 3D cultures as well as hormone restriction conditions (Brodaczewska et al. 2016; Czarnecka et al. 2016; Bielecka et al. 2017; Maliszewska-Olejniczak et al. 2018).

In the field of RCC only a few studies investigating IGFs were published and reported conflicting results: varying degrees of IGFIR expression, as well as complete absence of IGF1R and its ligand IGF1 in RCC tissues are known. As in the case of insulin and IR, the expression of the ligand (IGF1) and its receptor (IGF1R) within the same tumor could provide proof of an autocrine-paracrine signaling loop of RCC cells stimulation (Schips et al. 2004). In particular SN12K1 (metastatic RCC) cell line express autocrine IGF1 (Cheung et al. 2004), but this is not the case with RCC cell lines selected by us, therefore we believe this may be case-specific phenomenon, but is not ubiquitous phenomenon in RCC. Our result stay in accordance with pathological reports that show that the expression of IGF1R is not related to the expression of its ligands, neither in papillary nor in clear cell RCC tumors. Therefore, we provide physiological confirmation of the hypothesis that IGFs signaling in RCC is mediated mainly by circulating ligand proteins (IGF1 and IGF2) from sources other than RCC cancer tumor itself, as suggested before (Schips et al. 2004). We believe that significant impact on RCC cancer cells might be exerted by tumor-associated endothelial cells expressing IGF. Such interaction could promote RCC cells chemo-resistance, but also favor cancer stem cell phenotype (Cao et al. 2017; Youssef et al. 2017). More research is needed in the field, but co-culture bio-mimetic models should also be employed as we have indicated before (Bielecka et al. 2017; Kaminska et al. 2017).

Our results stay also in accordance with the fact that in healthy individuals only $25 \%$ of IGF1 is synthesized locally in kidney and acts as an autocrine or paracrine factor. On tissue level local IGF1 is generally limited to stromal cells and act on

Table 2 Concentration of insulin

\begin{tabular}{lllllll}
\hline & Control & Insulin & IGF1 & IGF2 & HNMPA & PPP \\
\hline $769-\mathrm{P}$ & $<0,04 \mathrm{ng} / \mathrm{ml}$ & $<0,04 \mathrm{ng} / \mathrm{ml}$ & $<0,04 \mathrm{ng} / \mathrm{ml}$ & $<0,04 \mathrm{ng} / \mathrm{ml}$ & $<0,04 \mathrm{ng} / \mathrm{ml}$ & $<0,04 \mathrm{ng} / \mathrm{ml}$ \\
$786-\mathrm{O}$ & $<0,04 \mathrm{ng} / \mathrm{ml}$ & $<0,04 \mathrm{ng} / \mathrm{ml}$ & $<0,04 \mathrm{ng} / \mathrm{ml}$ & $<0,04 \mathrm{ng} / \mathrm{ml}$ & $<0,04 \mathrm{ng} / \mathrm{ml}$ & $<0,04 \mathrm{ng} / \mathrm{ml}$ \\
PCS-400-010 & $<0,04 \mathrm{ng} / \mathrm{ml}$ & $<0,04 \mathrm{ng} / \mathrm{ml}$ & $<0,04 \mathrm{ng} / \mathrm{ml}$ & $<0,04 \mathrm{ng} / \mathrm{ml}$ & $<0,04 \mathrm{ng} / \mathrm{ml}$ & $<0,04 \mathrm{ng} / \mathrm{ml}$ \\
ACHN & $<0,04 \mathrm{ng} / \mathrm{ml}$ & $<0,04 \mathrm{ng} / \mathrm{ml}$ & $<0,04 \mathrm{ng} / \mathrm{ml}$ & $<0,04 \mathrm{ng} / \mathrm{ml}$ & $<0,04 \mathrm{ng} / \mathrm{ml}$ & $<0,04 \mathrm{ng} / \mathrm{ml}$ \\
HEK293 & $<0,04 \mathrm{ng} / \mathrm{ml}$ & $<0,04 \mathrm{ng} / \mathrm{ml}$ & $<0,04 \mathrm{ng} / \mathrm{ml}$ & $<0,04 \mathrm{ng} / \mathrm{ml}$ & $<0,04 \mathrm{ng} / \mathrm{ml}$ & $<0,04 \mathrm{ng} / \mathrm{ml}$ \\
CAKI-1 & $<0,04 \mathrm{ng} / \mathrm{ml}$ & $<0,04 \mathrm{ng} / \mathrm{ml}$ & $<0,04 \mathrm{ng} / \mathrm{ml}$ & $<0,04 \mathrm{ng} / \mathrm{ml}$ & $<0,04 \mathrm{ng} / \mathrm{ml}$ & $<0,04 \mathrm{ng} / \mathrm{ml}$ \\
CAKI-2 & $<0,04 \mathrm{ng} / \mathrm{ml}$ & $<0,04 \mathrm{ng} / \mathrm{ml}$ & $<0,04 \mathrm{ng} / \mathrm{ml}$ & $<0,04 \mathrm{ng} / \mathrm{ml}$ & $<0,04 \mathrm{ng} / \mathrm{ml}$ & $<0,04 \mathrm{ng} / \mathrm{ml}$ \\
\hline
\end{tabular}


Table 3 Concentration of IGF1

\begin{tabular}{lllllll}
\hline & Control & Insulin & IGF1 & IGF2 & HNMPA & PPP \\
\hline $769-\mathrm{P}$ & $<41 \mathrm{pg} / \mathrm{ml}$ & $<41 \mathrm{pg} / \mathrm{ml}$ & $81 \mathrm{pg} / \mathrm{ml}$ & $<41 \mathrm{pg} / \mathrm{ml}$ & $<41 \mathrm{pg} / \mathrm{ml}$ & $<41 \mathrm{pg} / \mathrm{ml}$ \\
$786-\mathrm{O}$ & $<41 \mathrm{pg} / \mathrm{ml}$ & $<41 \mathrm{pg} / \mathrm{ml}$ & $<41 \mathrm{pg} / \mathrm{ml}$ & $<41 \mathrm{pg} / \mathrm{ml}$ & $<41 \mathrm{pg} / \mathrm{ml}$ & $<41 \mathrm{pg} / \mathrm{ml}$ \\
PCS-400-010 & $<41 \mathrm{pg} / \mathrm{ml}$ & $<41 \mathrm{pg} / \mathrm{ml}$ & $<41 \mathrm{pg} / \mathrm{ml}$ & $<41 \mathrm{pg} / \mathrm{ml}$ & $<41 \mathrm{pg} / \mathrm{ml}$ & $<41 \mathrm{pg} / \mathrm{ml}$ \\
ACHN & $<41 \mathrm{pg} / \mathrm{ml}$ & $<41 \mathrm{pg} / \mathrm{ml}$ & $<41 \mathrm{pg} / \mathrm{ml}$ & $<41 \mathrm{pg} / \mathrm{ml}$ & $<41 \mathrm{pg} / \mathrm{ml}$ & $<41 \mathrm{pg} / \mathrm{ml}$ \\
HEK293 & $<41 \mathrm{pg} / \mathrm{ml}$ & $<41 \mathrm{pg} / \mathrm{ml}$ & $81 \mathrm{pg} / \mathrm{ml}$ & $<41 \mathrm{pg} / \mathrm{ml}$ & $<41 \mathrm{pg} / \mathrm{ml}$ & $<41 \mathrm{pg} / \mathrm{ml}$ \\
CAKI-1 & $<41 \mathrm{pg} / \mathrm{ml}$ & $<41 \mathrm{pg} / \mathrm{ml}$ & $115 \mathrm{pg} / \mathrm{ml}$ & $<41 \mathrm{pg} / \mathrm{ml}$ & $<41 \mathrm{pg} / \mathrm{ml}$ & $<41 \mathrm{pg} / \mathrm{ml}$ \\
CAKI-2 & $<41 \mathrm{pg} / \mathrm{ml}$ & $<41 \mathrm{pg} / \mathrm{ml}$ & $<41 \mathrm{pg} / \mathrm{ml}$ & $<41 \mathrm{pg} / \mathrm{ml}$ & $<41 \mathrm{pg} / \mathrm{ml}$ & $<41 \mathrm{pg} / \mathrm{ml}$ \\
\hline
\end{tabular}

adjacent (epithelial) cells that do not actually express IGF1. IGF1 detected in the proximal epithelial cells is most probably sequestrated from the circulation (Kamenicky et al. 2014). As we have shown it is both IGFs and insulin that stimulate RCC cells viability and proliferation. For HEK-293 cells it was previously defined that insulin, transferrin and specific lipid mix positively affect cell growth in serum-free media formulations, with optimal insulin concentration of $19,8 \mathrm{mg} / \mathrm{L}$ as defined in Box-Behnken experimental design analysis. These cells triplicated their maximum cell densities in the presence of FBS 9,3 $\times$ $10^{6}$ cells $/ \mathrm{ml}$ in comparison to serum restriction, while in the presence of optimal insulin-transferrin-lipid combination/ concentrations of supplements cells reached a maximum cell density of $5,4 \times 10^{6}$ cells $/ \mathrm{mL}$ at day 5 of the culture (Cervera et al. 2011). Our results prove the pro-proliferative effect of insulin and IGFs in exponential phase of cell culture. The timing of primary proliferative effect seem to stay in correlation with RCC cells doubling time, that is $45 \mathrm{~h}$ for $786-0$ cell line (Williams et al. 1978), and $32 \mathrm{~h}$ for ACHN, $36 \mathrm{~h}$ for Caki-1 cells, and 24-30 h for HEK293 cells (Cowley et al. 2014). The activating insulin concentration used in our model is within the insulin blood level, as the concentration of insulin is specific for kidney parenchyma and different that general serum concentration, that is in renal venous blood IN concentration is invariably lower than in the corresponding kidney arterial blood - with the mean arterial insulin level of $14.1 \mu \mathrm{U}$ and the mean venous level $9.3 \mu \mathrm{U}$ per $\mathrm{ml}(0.3 \mu \mathrm{g} / \mathrm{ml})$ while for IN 1 international unit IU = $0.0347 \mathrm{mg}$ (Chamberlain and Stimmler 1967). Moreover the concentration of insulin in the kidney is higher in proximal tubules than in the glomeruli (Aun et al. 1975). Our experimental design was used to support clinical relevance of these basic observations, since we used stimulation with $0.1 \mu \mathrm{g} / \mathrm{ml}$ that is physiologically detectable in the kidney, even though physiological concentration of insulin in humans serum in peripheral circulation is much lower $-0.5-5 \mathrm{ng} / \mathrm{ml}$ (Nakamura et al. 2015).

In normal kidney cells insulin has an inhibitory effect on renal gluconeogenesis, it suppress expression and activity of gluconeogenic enzymes, including phosphoenolpyruvate carboxykinase (PEPCK) and G6Pase (Gatica et al. 2013; Tiwari et al. 2013). As a consequence increased renal glucose-6-phosphatase gene expression is found in IR knock-out and enhanced gluconeogenesis is found when insulin is not able to execute its function in kidney cells (Tiwari et al. 2013). This is not true for RCC cells because in RCC gluconeogenic enzyme fructose-1,6-bisphosphatase 1 (FBP1) is depleted in majority of the cases ( $\mathrm{Li}$ et al. 2014). Therefore IR loss in RCC should be considered as proliferation dependent, but not metabolism - defining event. It may be therefore mechanism resembling vascular smooth muscle cell, that lacking the IR and characterized therefore by loss of canonical insulin signaling exhibit greater proliferation and migration rates compared to wild type cells. This phenomenon is characterized by increased activation of the ERK-1/2 and decreased $\mathrm{p} 27^{\mathrm{Kip} 1}$ in response to stimulation with physiological insulin (Lightell Jr. et al. 2011). As we have shown RCC cells compared with normal renal cells also exhibit greater proliferation and migration concomitant with IR loss. Such IR-loss mediated activity stay in opposite to breast cancer, where downregulation of IR inhibits cancer cell proliferation, angiogenesis and lymphangiogenesis (in animal model). More over downregulation of IR inhibits cancer metastasis in an athymic mouse breast cancer model, even in the presence of functional

Table 4 Concentration of IGF2

\begin{tabular}{lllllll}
\hline & Control & Insulin & IGF1 & IGF2 & HNMPA & PPP \\
\hline $769-\mathrm{P}$ & $<0,9 \mathrm{ng} / \mathrm{ml}$ & $<0,9 \mathrm{ng} / \mathrm{ml}$ & $<0,9 \mathrm{ng} / \mathrm{ml}$ & $4,2 \mathrm{ng} / \mathrm{ml}$ & $<0,9 \mathrm{ng} / \mathrm{ml}$ & $<0,9 \mathrm{ng} / \mathrm{ml}$ \\
$786-\mathrm{O}$ & $<0,9 \mathrm{ng} / \mathrm{ml}$ & $<0,9 \mathrm{ng} / \mathrm{ml}$ & $<0,9 \mathrm{ng} / \mathrm{ml}$ & $<0,9 \mathrm{ng} / \mathrm{ml}$ & $<0,9 \mathrm{ng} / \mathrm{ml}$ & $<0,9 \mathrm{ng} / \mathrm{ml}$ \\
PCS-400-010 & $<0,9 \mathrm{ng} / \mathrm{ml}$ & $<0,9 \mathrm{ng} / \mathrm{ml}$ & $<0,9 \mathrm{ng} / \mathrm{ml}$ & $<0,9 \mathrm{ng} / \mathrm{ml}$ & $<0,9 \mathrm{ng} / \mathrm{ml}$ & $<0,9 \mathrm{ng} / \mathrm{ml}$ \\
ACHN & $<0,9 \mathrm{ng} / \mathrm{ml}$ & $<0,9 \mathrm{ng} / \mathrm{ml}$ & $<0,9 \mathrm{ng} / \mathrm{ml}$ & $<0,9 \mathrm{ng} / \mathrm{ml}$ & $<0,9 \mathrm{ng} / \mathrm{ml}$ & $<0,9 \mathrm{ng} / \mathrm{ml}$ \\
HEK293 & $<0,9 \mathrm{ng} / \mathrm{ml}$ & $<0,9 \mathrm{ng} / \mathrm{ml}$ & $<0,9 \mathrm{ng} / \mathrm{ml}$ & $8,5 \mathrm{ng} / \mathrm{ml}$ & $<0,9 \mathrm{ng} / \mathrm{ml}$ & $<0,9 \mathrm{ng} / \mathrm{ml}$ \\
CAKI-1 & $<0,9 \mathrm{ng} / \mathrm{ml}$ & $<0,9 \mathrm{ng} / \mathrm{ml}$ & $<0,9 \mathrm{ng} / \mathrm{ml}$ & $<0,9 \mathrm{ng} / \mathrm{ml}$ & $<0,9 \mathrm{ng} / \mathrm{ml}$ & $<0,9 \mathrm{ng} / \mathrm{ml}$ \\
CAKI-2 & $<0,9 \mathrm{ng} / \mathrm{ml}$ & $<0,9 \mathrm{ng} / \mathrm{ml}$ & $<0,9 \mathrm{ng} / \mathrm{ml}$ & $<0,9 \mathrm{ng} / \mathrm{ml}$ & $<0,9 \mathrm{ng} / \mathrm{ml}$ & $<0,9 \mathrm{ng} / \mathrm{ml}$ \\
\hline
\end{tabular}


Table 5 Human Insulin Signaling Pathway gene expression analysis. Fold change with $\mathrm{p}$ value below

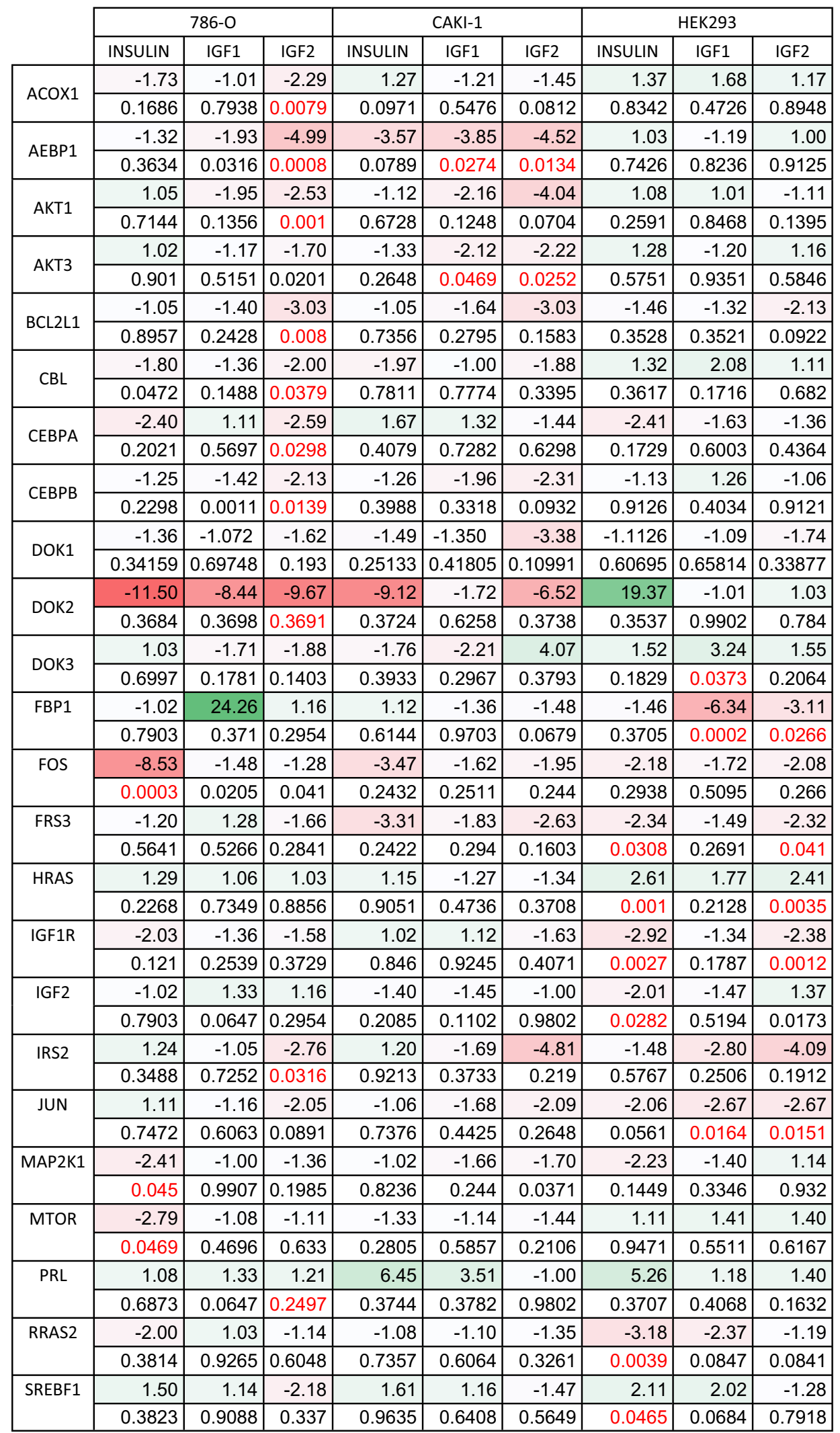

The fold change/regulation were calculated using delta delta CT method. In which delta CT is calculated between gene of interest (GOI) and an average of reference genes (HKG). followed by delta-delta CT calculations (delta CT (Test Group)-delta CT (Control Group)). Fold Change is then calculated using $2^{\wedge}(-$ delta delta CT) formula 
Fig. 4 Human Insulin Signaling Pathway gene expression analysis. Among 84 genes which were assessed with $\mathrm{RT}^{2}$ Profiler ${ }^{\mathrm{TM}}$ PCR Array Human Insulin Signaling Pathway (Qiagen) the change in expression was revealed in expression of genes related to insulin-associated proteins (DOK1-3, INS, FRS3, IRS1-2, IGF1R), transcription regulators (AEBP1), PI3 kinase signaling (AKT1, BCL2L1, MTOR), MAP Kinase Signaling (FOS, MAP2K1, HRAS, RRAS) as well as carbohydrate (FBP1) and lipid metabolism (ACOX1)
786-0

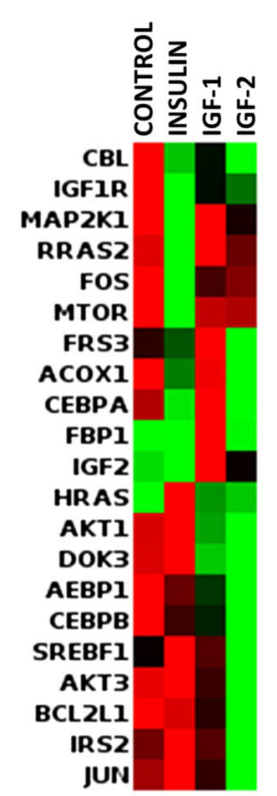

CAKI-1

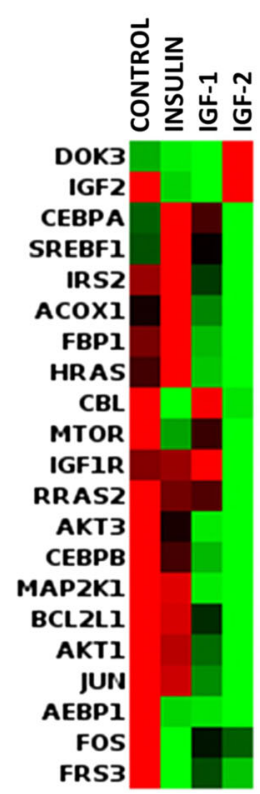

HEK293

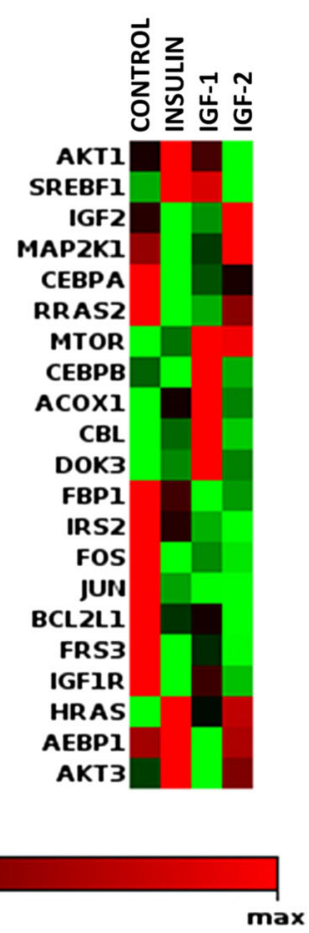

Magnitude of gene expression

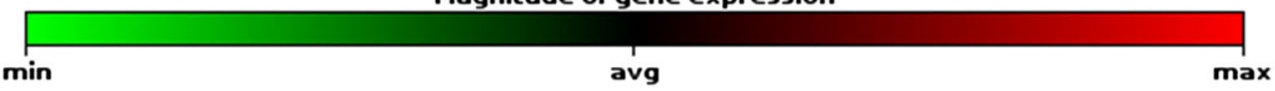

IGF1R (Zhang et al. 2010), but these cells represent different metabolic abnormalities and FBP mediated metabolism deregulation (Hsieh and Cheng 2016).

The lack of IR receptor on RCC cells lines does not abrogate insulin activity on RCC cells, as analyzed cell lines are responsive to insulin stimulation. As we have shown Insulin may influence RCC cells growth through IGF1R receptor stimulation, what is suggested by receptor phosphorylation tests results. Insulin activity on RCC cells is a result of the phenomenon that both receptors - IR and IGFR, as well as their heterodimers - can bind all three ligands (insulin, IGF1I and IGF2), although with varying affinities. In fact IGFs bind the primary binding site of IGF1R in mode equivalent to that of insulin to IR. This is supported by high degree of similarity of receptor-binding surfaces to those of insulin, and IR and IGF1R 50\% sequence homology (Cai et al. 2017; Xu et al. 2018). Phosphorylation of IGF1R in 786-O, Caki-2 and HEK293 cell lines is probably the mechanism through which insulin can affect cells activity despite the lack of insulin receptors on RCC cell lines. Also IGF1 and IGF2 induced IR phosphorylation in these cells (Fig. 1c, d). It may potentiate its stimulating strength as IGFs can influence cells growth and proliferation through IGF1R- and IR-dependent mechanisms. At the same time IN stimulation results in minor increase in $P R L$ gene expression in Caki-1 and HEK293 cell lines. This data is consistent with the rest of our results the insulin stimulation affects gene expression in cell lines missing insulin receptor, as described before (Siddle 2012).

Although high degree of homology, IR and IGF1R mediate different and distinct biological cellular functions. Biological processes modulated by these two receptors are different despite common intracellular signaling pathways activated. IGF1R induce more activation of Shc and Gab-1 proteins and more potent regulation of genes involved in proliferation, which result in final mitogenic activity (Cai et al. 2017). IGF1R signaling is also responsible for the maintenance of the transformed phenotype by modulating cancer cell motility, adhesion and angiogenesis (Schips et al. 2004). In our analysis DOK-1 gene expression has been shown as deregulated upon IGFR signaling which stay in accordance with data of these gene being unfavorable prognostic marker in renal cancer in The Human Protein Atlas. DOK1 tumor suppressor gene encodes an adapter protein that acts as a negative regulator of several signaling pathways. In particular DOK1 activation inhibits cell proliferation, down regulates MAP kinase activity, has inhibitory effect on leukemogenesis as well as promotes cell motility and apoptosis (Siouda et al. 2014). In terms of RCC specific signaling pathways deregulation it was previously reported that receptor for activated $\mathrm{C}$ kinase 1 (RACK1) is a direct mediator between loss of $\mathrm{pVHL}$ function and IGF1R signaling in RCC tumor cells. Upon IGF1 stimulation, pVHL-deficient RCC cells exhibit high rate of RACK1/IGF1R binding and upregulate IGF1R tyrosine kinase activity, with subsequent phosphoinositide 3-kinase/serine-threonine kinase Akt (PI3K/Akt) signaling and matrix metalloproteinase-2 (MMP2) activity resulting in high RCC cells invasiveness (He et al. 2011).

In previous studies clinical significance of IGF-1R was assessed by measuring IGF-1R levels in tissue samples of RCC and non-malignant kidneys. In the analysis of 21 paired specimens higher levels of IGF-1R mRNA were observed in the RCC 
tumors compared with benign kidney (Yuen et al. 2007). What is more it was showed that antitumor agents - mTOR inhibitors inadvertently activate the Akt-signaling pathway through an IGF-1R-dependent mechanism (Wan et al. 2007). In the study by Cardillo et al., it was presented that blockade of IGF-1 binding to IGF-1R and downregulation of this receptor are equally effective in inhibiting RCC cell lines growth and combined with mTOR inhibitor - temsirolimus works in synergy. Altogether it suggest new possible approach for treating RCC (Cardillo et al. 2013; Matyszewski et al. 2015a, b, c; Solarek et al. 2015; Tracz et al. 2016). Nevertheless IR and IGF receptors therapies should be developed with caution, as kinase independent biological activities have been described for these receptors (Janku et al. 2013), as well as IGF-2 activation upon IGF-1 blockage (ElShewy et al. 2007), which seems to be responsible for HEK293 cells viability we report in the presence of inhibitors.

Is this study, we demonstrate that insulin and IGFs are stimulatory factors for RCC cells growth and migration. We also prove that, despite the down-regulation of insulin receptors expression, RCC cells are responsive to insulin stimulation via the IGF1R. In the tumorigenesis process RCC cells do not obtain insulin secretory function and do not activate insulin autocrine stimulation. RCC cell also do not secret significant amount of IGF1 or IGF2, so autocrine stimulation loop in RCC is not responsible for activator effect. As opposed to earlier predictions insulin and IGFs stimulations lead to decrease in expression of many genes of PI3K-AktmTOR and Ras-MAPK pathways. These data together are consistent with the conclusion that IGFs and insulin may play a stimulatory role in renal cancer tumorigenesis and progression.

Acknowledgments This research have been supported by National Science Centre UMO-2012/05/D/NZ5/01844.

\section{Compliance with ethical standards}

Conflict of interest The authors indicate no potential conflict of interest.

Open Access This article is distributed under the terms of the Creative Commons Attribution 4.0 International License (http:// creativecommons.org/licenses/by/4.0/), which permits unrestricted use, distribution, and reproduction in any medium, provided you give appropriate credit to the original author(s) and the source, provide a link to the Creative Commons license, and indicate if changes were made.

\section{References}

Aun F, Meguid MM, Soeldner JS, Stolf NA (1975) Urinary insulin levels in health and disease-a concise review. Postgrad Med J 51(599): $622-626$
Bielecka ZF, Maliszewska-Olejniczak K, Safir IJ, Szczylik C, Czarnecka AM (2017) Three-dimensional cell culture model utilization in cancer stem cell research. Biol Rev Camb Philos Soc 92(3):1505-1520

Bray F, Ferlay J, Soerjomataram I, Siegel RL, Torre LA, Jemal A (2018) Global cancer statistics 2018: GLOBOCAN estimates of incidence and mortality worldwide for 36 cancers in 185 countries. CA Cancer J Clin 68(6):394-424

Brodaczewska KK, Szczylik C, Fiedorowicz M, Porta C, Czarnecka AM (2016) Choosing the right cell line for renal cell cancer research. Mol Cancer 15(1):83

Cai W, Sakaguchi M, Kleinridders A, Gonzalez-Del Pino G, Dreyfuss JM, O'Neill BT, Ramirez AK, Pan H, Winnay JN, Boucher J, Eck MJ, Kahn CR (2017) Domain-dependent effects of insulin and IGF1 receptors on signalling and gene expression. Nat Commun 8: 14892

Cao Z, Scandura JM, Inghirami GG, Shido K, Ding BS, Rafii S (2017) Molecular checkpoint decisions made by subverted vascular niche transform indolent tumor cells into Chemoresistant Cancer stem cells. Cancer Cell 31(1):110-126

Cardillo TM, Trisal P, Arrojo R, Goldenberg DM, Chang CH (2013) Targeting both IGF-1R and mTOR synergistically inhibits growth of renal cell carcinoma in vitro. BMC Cancer 13:170

Cervera, L., Gutierrez, S., Godia, F., Segura, M. M. (2011) Optimization of HEK 293 cell growth by addition of non-animal derived components using design of experiments. BMC proc 5 Suppl 8: P126

Chamberlain MJ, Stimmler L (1967) The renal handling of insulin. J Clin Invest 46(6):911-919

Chen J, Nagle AM, Wang YF, Boone DN, Lee AV (2018) Controlled dimerization of insulin-like growth factor-1 and insulin receptors reveals shared and distinct activities of holo and hybrid receptors. J Biol Chem 293(10):3700-3709

Cheung CW, Vesey DA, Nicol DL, Johnson DW (2004) The roles of IGF-I and IGFBP-3 in the regulation of proximal tubule, and renal cell carcinoma cell proliferation. Kidney Int 65(4):1272-1279

Cowley GS, Weir BA, Vazquez F, Tamayo P, Scott JA, Rusin S, EastSeletsky A, Ali LD, Gerath WF, Pantel SE, Lizotte PH, Jiang G, Hsiao J, Tsherniak A, Dwinell E, Aoyama S, Okamoto M, Harrington W, Gelfand E, Green TM, Tomko MJ, Gopal S, Wong TC, Li H, Howell S, Stransky N, Liefeld T, Jang D, Bistline J, Hill Meyers B, Armstrong SA, Anderson KC, Stegmaier K, Reich M, Pellman D, Boehm JS, Mesirov JP, Golub TR, Root DE, Hahn WC (2014) Parallel genome-scale loss of function screens in 216 cancer cell lines for the identification of context-specific genetic dependencies. Sci Data 1:140035

Czarnecka AM, Matak D, Szymanski L, Czarnecka KH, Lewicki S, Zdanowski R, Brzezianska-Lasota E, Szczylik C (2016) Triiodothyronine regulates cell growth and survival in renal cell cancer. Int J Oncol 49(4):1666-1678

Datta K, Nambudripad R, Pal S, Zhou M, Cohen HT, Mukhopadhyay D (2000) Inhibition of insulin-like growth factor-I-mediated cell signaling by the von Hippel-Lindau gene product in renal cancer. J Biol Chem 275(27):20700-20706

El-Shewy HM, Lee MH, Obeid LM, Jaffa AA, Luttrell LM (2007) The insulin-like growth factor type 1 and insulin-like growth factor type 2/mannose-6-phosphate receptors independently regulate ERK1/2 activity in HEK293 cells. J Biol Chem 282(36):26150-26157

Frasca F, Pandini G, Sciacca L, Pezzino V, Squatrito S, Belfiore A, Vigneri R (2008) The role of insulin receptors and IGF-I receptors in cancer and other diseases. Arch Physiol Biochem 114(1):23-37

Gatica R, Bertinat R, Silva P, Carpio D, Ramirez MJ, Slebe JC, San Martin R, Nualart F, Campistol JM, Caelles C, Yanez AJ (2013) Altered expression and localization of insulin receptor in proximal tubule cells from human and rat diabetic kidney. J Cell Biochem 114(3):639-649

Grada A, Otero-Vinas M, Prieto-Castrillo F, Obagi Z, Falanga V (2017) Research techniques made simple: analysis of collective cell 
migration using the wound healing assay. J Invest Dermatol 137(2): e11-e16

He X, Wang J, Messing EM, Wu G (2011) Regulation of receptor for activated $\mathrm{C}$ kinase 1 protein by the von Hippel-Lindau tumor suppressor in IGF-I-induced renal carcinoma cell invasiveness. Oncogene 30(5):535-547

Hsieh JJ, Cheng EH (2016) The panoramic view of clear cell renal cell carcinoma metabolism: values of integrated global cancer metabolomics. Transl Androl Urol 5(6):984-986

Janku F, Huang HJ, Angelo LS, Kurzrock R (2013) A kinase-independent biological activity for insulin growth factor-1 receptor (IGF-1R) : implications for inhibition of the IGF-1R signal. Oncotarget 4(3): 463-473

Kamenicky P, Mazziotti G, Lombes M, Giustina A, Chanson P (2014) Growth hormone, insulin-like growth factor-1, and the kidney: pathophysiological and clinical implications. Endocr Rev 35(2):234 281

Kaminska K, Czarnecka AM, Khan MI, Fendler W, Klemba A, Krasowski P, Bartnik E, Szczylik C (2017) Effects of cell-cell crosstalk on gene expression patterns in a cell model of renal cell carcinoma lung metastasis. Int J Oncol

Labochka D, Moszczuk B, Kukwa W, Szczylik C, Czarnecka AM (2016) Mechanisms through which diabetes mellitus influences renal cell carcinoma development and treatment: a review of the literature. Int J Mol Med 38(6):1887-1894

Larsson SC, Wolk A (2011) Diabetes mellitus and incidence of kidney cancer: a meta-analysis of cohort studies. Diabetologia 54(5):10131018

Leboulleux S, Gaston V, Boulle N, Le Bouc Y, Gicquel C (2001) Loss of heterozygosity at the mannose 6-phosphate/insulin-like growth factor 2 receptor locus: a frequent but late event in adrenocortical tumorigenesis. Eur J Endocrinol 144(2):163-168

Li B, Qiu B, Lee DS, Walton ZE, Ochocki JD, Mathew LK, Mancuso A, Gade TP, Keith B, Nissim I, Simon MC (2014) Fructose-1,6bisphosphatase opposes renal carcinoma progression. Nature 513(7517):251-255

Lightell DJ Jr, Moss SC, Woods TC (2011) Loss of canonical insulin signaling accelerates vascular smooth muscle cell proliferation and migration through changes in p27Kip1 regulation. Endocrinology 152(2):651-658

Maliszewska-Olejniczak K, Brodaczewska KK, Bielecka ZF, Czarnecka AM (2018) Three-dimensional cell culture model utilization in renal carcinoma Cancer stem cell research. Methods Mol Biol 1817:4766

Matyszewski A, Czarnecka A, Kawecki M, Korzen P, Safir IJ, Kukwa W, Szczylik C (2015a) Impaired glucose metabolism treatment and carcinogenesis. Oncol Lett 10(2):589-594

Matyszewski A, Czarnecka AM, Korzen P, Safir IJ, Kukwa W, Szczylik C (2015b) The Role of Diabetes in Molecular Pathogenesis of Cancer Current Signal Transduction Therapy. 10(1):10-16

Matyszewski A, Czarnecka AM, Solarek W, Korzen P, Safir IJ, Kukwa W, Szczylik C (2015c) Molecular basis of carcinogenesis in diabetic patients (review). Int J Oncol 46(4):1435-1443

Murai M, Oya M (2004) Renal cell carcinoma: etiology, incidence and epidemiology. Curr Opin Urol 14(4):229-233

Nakamura N, Matsui T, Ishibashi Y, Yamagishi S (2015) Insulin stimulates SGLT2-mediated tubular glucose absorption via oxidative stress generation. Diabetol Metab Syndr 7:48

Pollak M (2008) Insulin and insulin-like growth factor signalling in neoplasia. Nat Rev Cancer 8(12):915-928

Reuveni H, Flashner-Abramson E, Steiner L, Makedonski K, Song R, Shir A, Herlyn M, Bar-Eli M, Levitzki A (2013) Therapeutic destruction of insulin receptor substrates for cancer treatment. Cancer Res 73(14):4383-4394

Sasaki M, Sasako T, Kubota N, Sakurai Y, Takamoto I, Kubota T, Inagi R, Seki G, Goto M, Ueki K, Nangaku M, Jomori T, Kadowaki T (2017) Dual regulation of gluconeogenesis by insulin and glucose in the proximal tubules of the kidney. Diabetes 66(9):2339-2350

Schips L, Zigeuner R, Ratschek M, Rehak P, Ruschoff J, Langner C (2004) Analysis of insulin-like growth factors and insulin-like growth factor I receptor expression in renal cell carcinoma. Am J Clin Pathol 122(6):931-937

Siddle K (2012) Molecular basis of signaling specificity of insulin and IGF receptors: neglected corners and recent advances. Front Endocrinol (Lausanne) 3:34

Siegel RL, Miller KD, Jemal A (2016) Cancer statistics, 2016. CA Cancer $\mathrm{J}$ Clin 66(1):7-30

Siouda M, Frecha C, Accardi R, Yue J, Cuenin C, Gruffat H, Manet E, Herceg Z, Sylla BS, Tommasino M (2014) Epstein-Barr virus downregulates tumor suppressor DOK1 expression. PLoS Pathog 10(5): e1004125

Slaaby R, Schaffer L, Lautrup-Larsen I, Andersen AS, Shaw AC, Mathiasen IS, Brandt J (2006) Hybrid receptors formed by insulin receptor (IR) and insulin-like growth factor I receptor (IGF-IR) have low insulin and high IGF-1 affinity irrespective of the IR splice variant. J Biol Chem 281(36):25869-25874

Solarek W, Czarnecka AM, Escudier B, Bielecka ZF, Lian F, Szczylik C (2015) Insulin and IGFs in renal cancer risk and progression. Endocr Relat Cancer 22(5):R253-R264

Takahashi M, Inoue T, Huang M, Numakura K, Tsuruta H, Saito M, Maeno A, Nakamura E, Narita S, Tsuchiya N, Habuchi T (2017) Inverse relationship between insulin receptor expression and progression in renal cell carcinoma. Oncol Rep 37(5):2929-2941

Tiwari S, Singh RS, Li L, Tsukerman S, Godbole M, Pandey G, Ecelbarger CM (2013) Deletion of the insulin receptor in the proximal tubule promotes hyperglycemia. J Am Soc Nephrol 24(8): $1209-1214$

Tracz AF, Szczylik C, Porta C, Czarnecka AM (2016) Insulin-like growth factor-1 signaling in renal cell carcinoma. BMC Cancer 16:453

Wan X, Harkavy B, Shen N, Grohar P, Helman LJ (2007) Rapamycin induces feedback activation of Akt signaling through an IGF-1Rdependent mechanism. Oncogene 26(13):1932-1940

Williams RD, Elliott AY, Stein N, Fraley EE (1978) In vitro cultivation of human renal cell cancer. II Characterization of cell lines In Vitro 14(9):779-786

Xu Y, Kong GK, Menting JG, Margetts MB, Delaine CA, Jenkin LM, Kiselyov VV, De Meyts P, Forbes BE, Lawrence MC (2018) How ligand binds to the type 1 insulin-like growth factor receptor. Nat Commun 9(1):821

Youssef A, Aboalola D, Han VK (2017) The roles of insulin-like growth factors in mesenchymal stem cell niche. Stem Cells Int 2017: 9453108

Yuen JS, Cockman ME, Sullivan M, Protheroe A, Turner GD, Roberts IS, Pugh CW, Werner H, Macaulay VM (2007) The VHL tumor suppressor inhibits expression of the IGF1R and its loss induces IGF1R upregulation in human clear cell renal carcinoma. Oncogene 26(45): 6499-6508

Zhang H, Fagan DH, Zeng X, Freeman KT, Sachdev D, Yee D (2010) Inhibition of cancer cell proliferation and metastasis by insulin receptor downregulation. Oncogene 29(17):2517-2527

Publisher's note Springer Nature remains neutral with regard to jurisdictional claims in published maps and institutional affiliations. 